\title{
Perancangan E-Learning di SMAN 1 Margahayu
}

\author{
M Wicaksana ${ }^{1}$, M D Rahmatya ${ }^{2}$ \\ Program Studi Sistem Informasi, Universitas Komputer Indonesia ${ }^{1,2}$ \\ Jl. Dipatiukur No. 112-116, Bandung, 40132, Indonesia ${ }^{1,2}$ \\ e-mail: mayugawicaksana18@gmail.com¹,*myrna@email.unikom.ac.id ${ }^{2}$ \\ diterima: 2 Juli 2019 \\ direvisi: 8 Agustus 2019 \\ dipublikasi: 1 September 2019
}

\begin{abstract}
Abstrak
Kegiatan belajar mengajar di sekolah umumnya terbatas pada pertemuan yang dilakukan di kelas. Ketidakhadiran pengajar menjadi salah satu penyebab kegiatan belajar mengajar tidak berlangsung. Hal ini, berdampak pada tidak tersampaikannya materi pada siswa. SMAN 1 Margahayu merupakan salah satu lembaga pendidikan yang mengalani hal serupa. Selain itu, SMAN 1 Marhagayu belum menerapkan sistem e-learning. Sementara itu, e-learning dapat menjadi solusi dalam permasalahan ini. Tujuan penelitian ini ialah membangun rancangan e-learning pada SMAN 1 Margahayu. Metode pendekatan sistem yang digunakan adalah pendekatan berbasis objek dengan metode pengembangan sistem,prototype. Tools yang digunakan dalam penelitian ini ialah UML. Dengan adanya e-learning, pengajar dapat memberikan materi bahkan jika pertemuan di sekolah tidak dapat terjadi. Bukan hanya itu, murid yang absen di kelas tidak akan tertinggal materi pelajaran. Manfaat lain ialah siswa dapat berdiskusi mengenai materi pelajaran meski di luar jam pelajaran serta memungkinkan siswa mendapatkan materi pendukung selain yang sudah pengajar sampaikan di kelas. Oleh karena itu, perancangan e-learning ini dapat mendukung proses kegiatan belajar mengajar dan menjadi cara baru bagi pengajar dan siswa untuk berinteraksi.
\end{abstract}

Kata kunci: e-learning, pembelajaran elektronik, e-learning system

\begin{abstract}
Teaching and learning activities in schools are generally limited to meetings conducted in class. The absence of the teacher is one of the reasons why teaching and learning activities do not take place. This has an impact on the non-delivery of material to students. SMAN 1 Margahayu is one of the educational institutions that has the same thing. In addition, SMAN 1 Marhagayu has not implemented an e-learning system. Meanwhile, e-learning can be a solution to this problem. The purpose of this study was to develop an e-learning design at SMAN 1 Margahayu. The system approach method used is an object-based approach with a system development method, namely prototype. The tools used in this study are UML. With e-learning, teachers can provide material even if meetings at school cannot occur. Not only that, students who are absent in class will not be left behind in the subject matter. Another benefit is that students can discuss subject matter even outside of school hours and allow students to get support material other than those already taught in class. Therefore, the design of e-learning can support the process of teaching and learning activities and become a new way for teachers and students to interact.
\end{abstract}

Keywords: e-learning, electronic learning, e-learning system 


\section{Pendahuluan}

E-learning merupakan pembelajaran jarak jauh yang menggunakan internet [1]. Elearning menggabungkan metode pengajaran dan teknologi sebagai sarana dalam belajar. E-learning menggabungkan penyampaian materi secara digital yang terdiri dari dukungan dan layanan dalam belajar [2].

E-learning mengubah model pembelajaran tradisional menjadi visual dan tanpa tatap muka. Pengajar dapat menyediakan bahan pelajaran untuk siswa, mengontrol materi yang diajarkan, mengekplorasi kegiatan masing-masing peserta, seperti pengumpulan tugas. Pengajar juga dapat mengatur chat online dengan peserta, mengumumkan beberapa informasi dan memberikan masukan berharga bagi siswa [3].

SMAN 1 Margahayu belum memanfaatkan sistem e-learning. Proses pembelajaran masih dilakukan melalui pertemuan di kelas. Begitupun dalam pemberian tugas, latihan dan pemberian nilai tugas dan latihan. Sementara itu, telah banyak penelitian yang membuktikan manfaat $e$-learning dalam mendukung proses pembelajaran.

Penelitian yang dilakukan di Jawa Tengah pada tahun 2011 menyatakan bahwa tingkat pemanfaatan e-learning berpengaruh positif dan signifikan terhadap motivasi belajar dan kinerja individu, motivasi berpengaruh positif terhadap hasil belajar. Walaupn begitu, tingkat pemanfaatan e-learning tidak secara signifikan berpengaruh terhadap hasil belajar [4]. Penelitian lain yang dilakukan pada tahun 2012 di Semarang memperoleh hasil bahwa sistem e-learning sangat mudah dipahami dan sangat berguna dalam membantu proses perkulihan dengan manajemen pengguna, manajemen materi dan manajemen soal yang mudah [5].

Adapun penelitian terdahulu terkait rancangan e-learning mata pelajaran Biologi pada SMAN 15 Bandung tahun 2015, menghasilkan sistem informasi pembelajaran online. Sistem informasi ini berfokus pada penyaluran materi, unggah tugas, latihan secara online dan forum diskusi pada mata pelajaran Biologi [6]. Namun, penelitian ini tidak menangani pengolahan nilai tugas maupun latihan yang dilakukan secara online dan hanya diterapkan pada satu mata perlajaran..

\section{Kajian Pustaka}

Sistem adalah kumpulan beberapa prosedur yang terhubung untuk menyelesaikan suatu tujuan tertentu [7]. Informasi adalah sebuah data yang diproses atau data yang memiliki arti setelah diolah sehingga berguna bagi yang menerima [8]. Sistem informasi merupakan gabungan dari komponen dalam suatu organisasi yang berkaitan dengan proses membuatan dan aliran informasi. Komponen sistem informasi, yaitu input, proses, output, teknologi, basis data dan kontrol [7].

E-learning merupakan pemanfaatan teknologi informasi sebagai fasilitas pendukung proses belajar mengajar dan memberikan fleksibilitas, interaktivitas dan visualisasi. $E$ learning menggunakan jaringan internet dan menyimpan serta mendistribusikan pembelajaran dan informasi [9].

Berdasarkan hasil penelitian yang dilakukan Much. Fuad S. di UAD pada tahun 2017, e-learning berperan bukan menggantikan pembelajaran secara tatap muka tetapi mengkombinasikan antara pembelajaran melalui e-learning dengan pembelajaran secara tatap muka. Penggunaan e-learning dapat lebih dimaksimalkan dan memberikan bekal kepada mahasiswa saat bekerja di era digital [10]. 


\section{Metode Penelitian}

Metode pendekatan sistem yang digunakan ialah berorientasi pada objek. Metode pengembangan sistem yang digunakan, yaitu metode prototype. Metode pengembangan prototype terdiri dari 3 tahapan, yaitu analisis kebutuhan, pembangunan prototype, dan evaluasi prototype.

Alat bantu analisis dan perancangan yang digunakan ialah UML (Unified Modeling Language) yang terdiri dari : usecase diagram, scenario usecase, activity diagram, sequence diagram, class diagram, deployment diagram dan component diagram.

\section{Hasil dan Pembahasan}

Aktor yang terlibat dalam rancangan e-learning ini, yaitu admin, pengajar dan siswa. Aktivitas yang dianalisis ialah penyampaian materi, pemberian dan penilaian tugas dan latihan dan kegiatan diskusi. Hasil analisis kemudian diilustrasikan dalam usecase dan activity diagram. Use case yang diusulkan seperti pada gambar 1 .

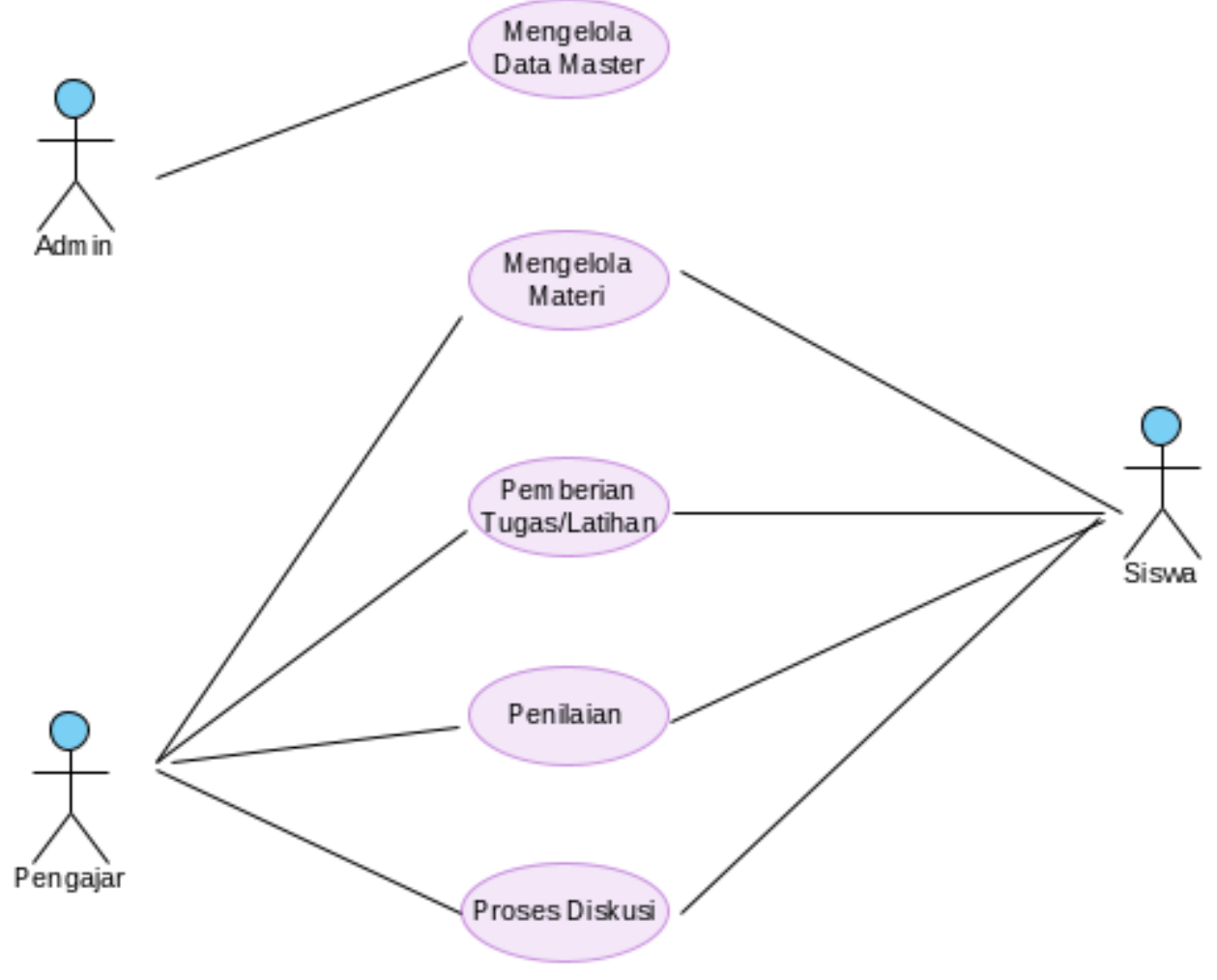

Gambar 1 Usecase yang diusulkan

Gambaran umum dari usecase tersebut dijabarkan dalam activity diagram pada gambar 2. Berikut activity diagram yang diusulkan, yaitu activity diagram mengelola materi, pemberian tugas/latihan, penilaian, dan proses diskusi. 
Volume 9 Nomor 2 Edisi September 2019

P-ISSN 2088-2270, E-ISSN 2655-6839

DOI 10.34010/jati.v9i2

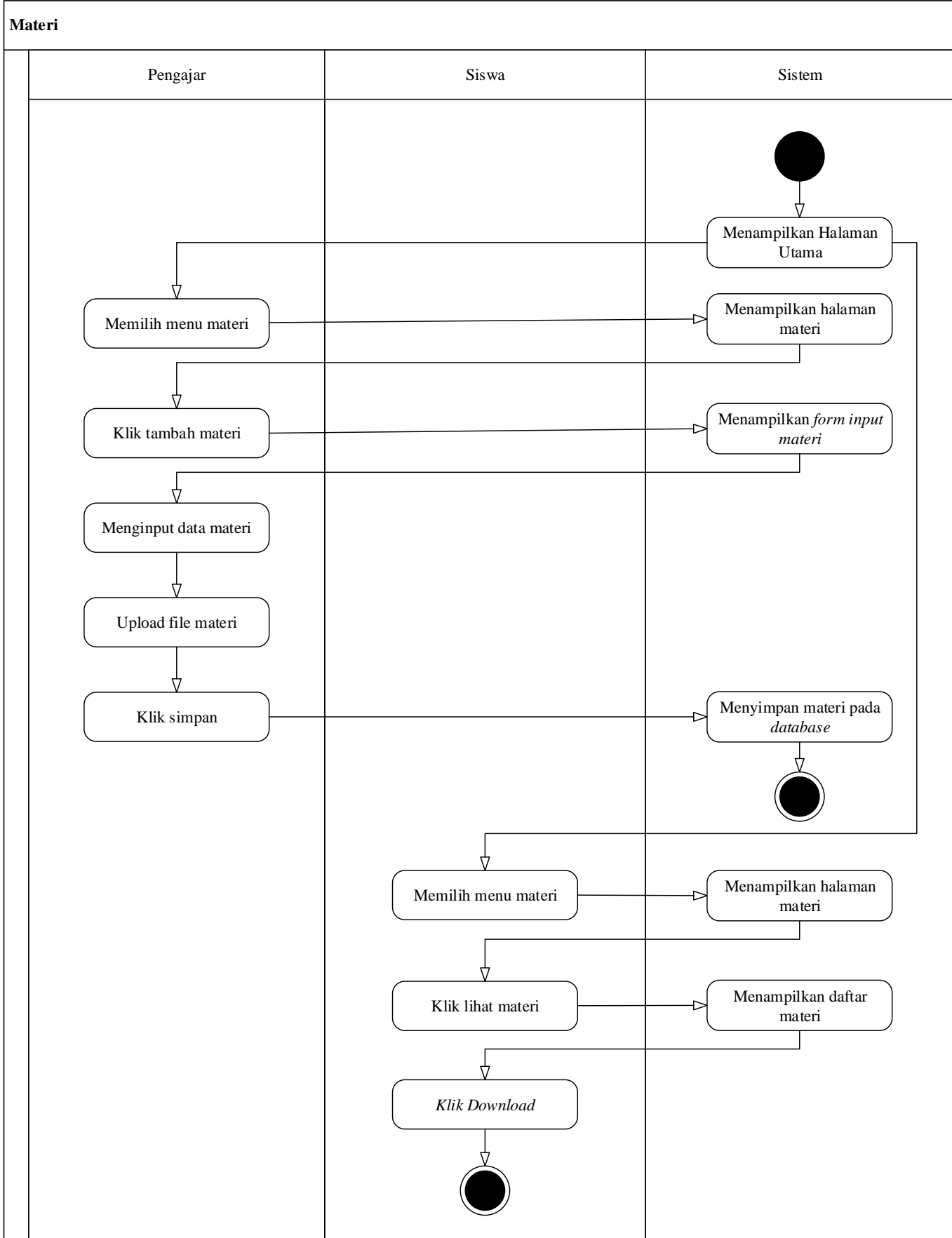

Gambar 1 Activity Diagram Penyampaian Materi

Pada acitivity diagram pemberian materi, pengajar hanya dapat memberikan materi sesuai dengan mata pelajaran yang diampunya. Hal ini berdasarkan pada tugas mengajar masing-masing pengajar di awal tahun ajar. Begitupun dengan siswa yang hanya dapat mengambil materi berdasarkan pengajarnya. 


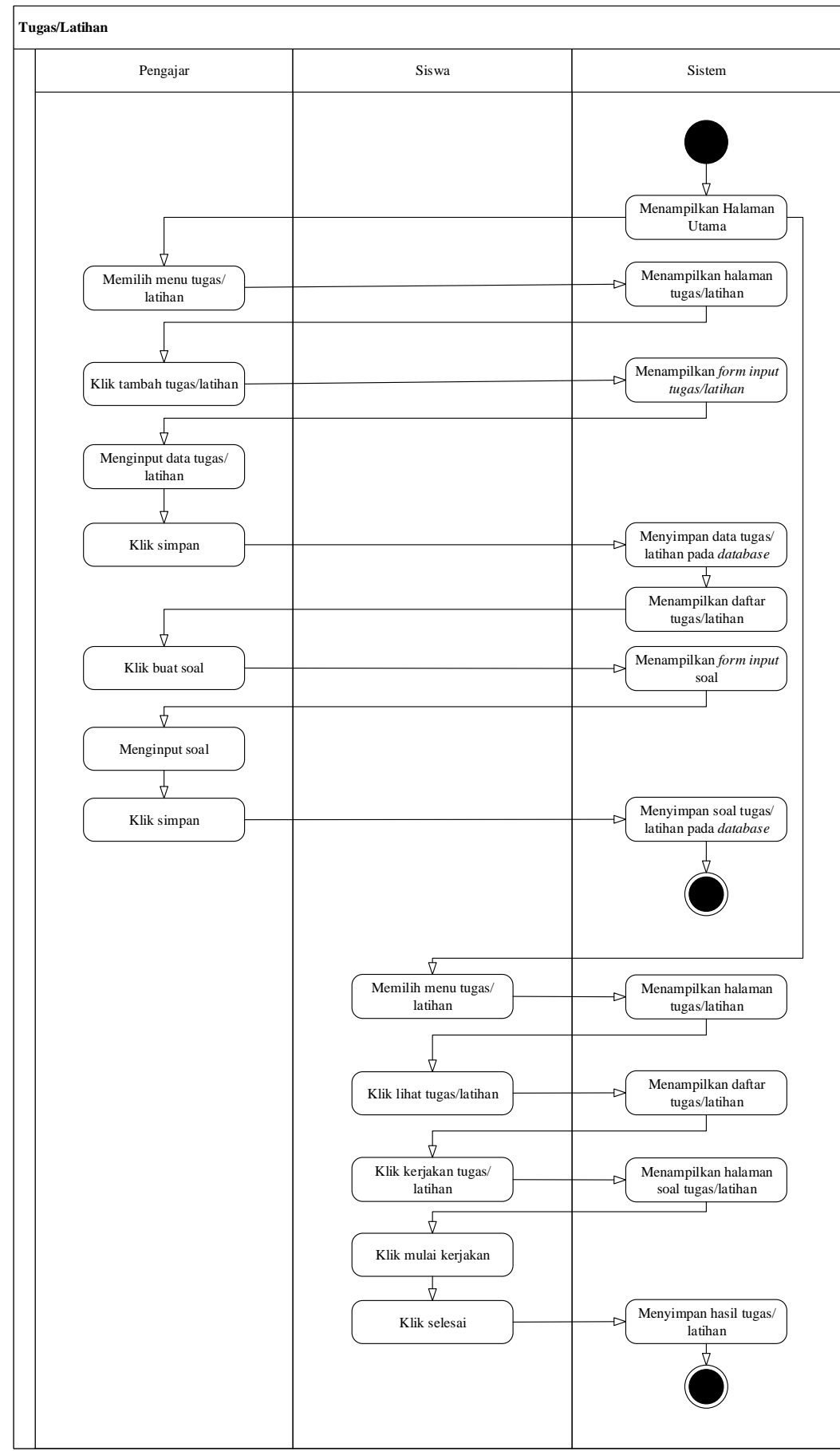

Gambar 2 Acitivity Diagram Tugas dan Latihan Online

Begitupun pada activity diagram tugas dan latihan soal seperti terlihat pada gambar 3. Pengajar hanya memberikan tugas dan latihan pada mata pelajaran yang diampunya. Begitu pula siswa hanya dapat mengerjakan tugas dan latihan berdasarkan mata pelajaran yang diambilnya. Siswa juga dapat melihat nilai tugas dan latihan yang telah dikerjakannya. Hal ini dapat membantu siswa untuk mengevaluasi kemampuannya. Activity diagram seperti pada gambar 4. 


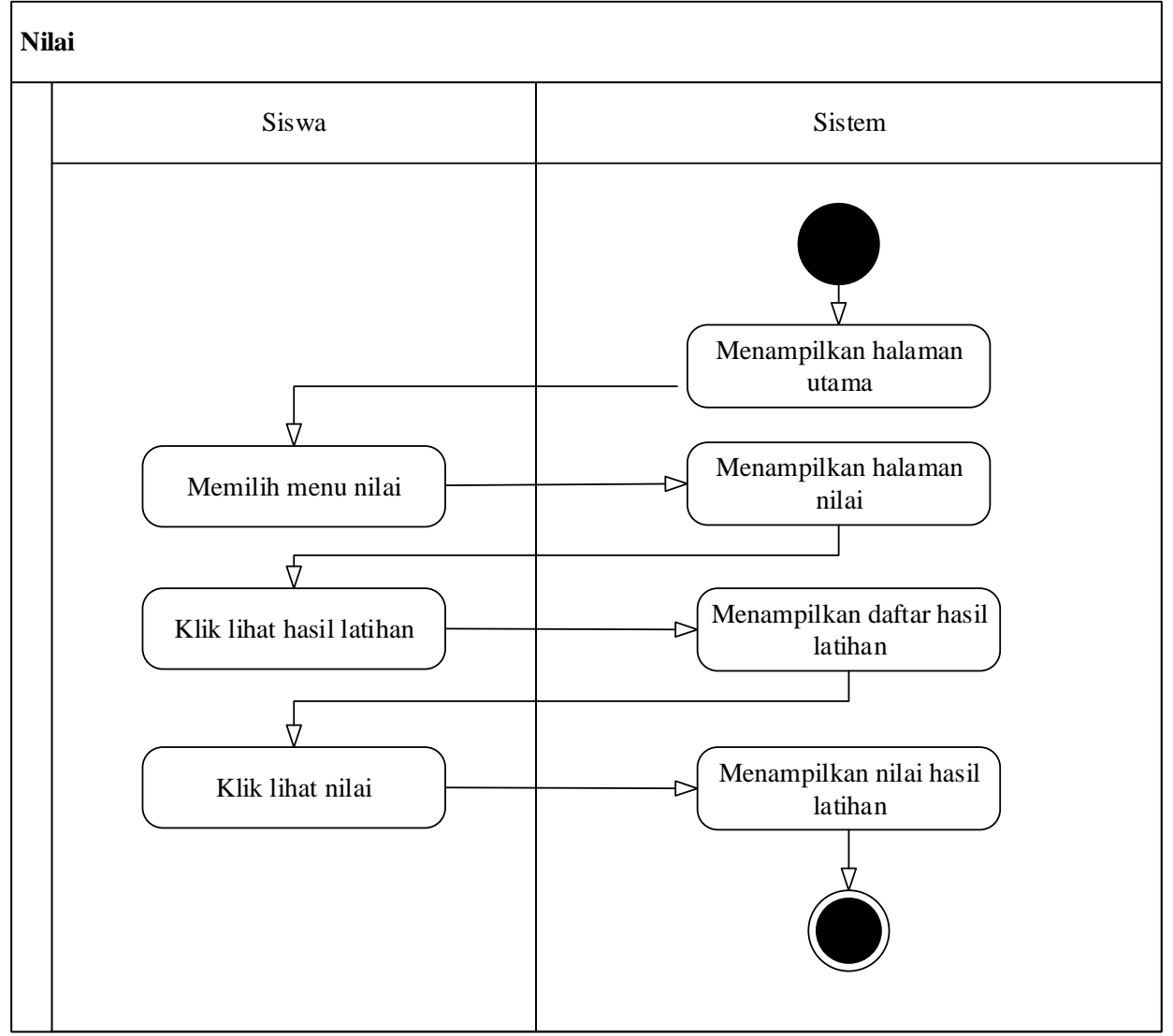

Gambar 4 Activity Diagram Nilai

Pengajar dapat membuka forum diskusi setelah kegiatan belajar mengajar di kelas selesai. Forum diskusi ini dibuka selama 3 hari setelah berakhirnya pertemuan di kelas dan akan berakhir setelah masa berlaku diskusi berakhir. Forum diskusi berguna sebagai sarana interaksi komunikatif antara pengajar dan siswa di luar jam pelajaran. Gambaran forum diskusi seperti pada gambar 5 . 
Volume 9 Nomor 2 Edisi September 2019

P-ISSN 2088-2270, E-ISSN 2655-6839

DOI 10.34010/jati.v9i2

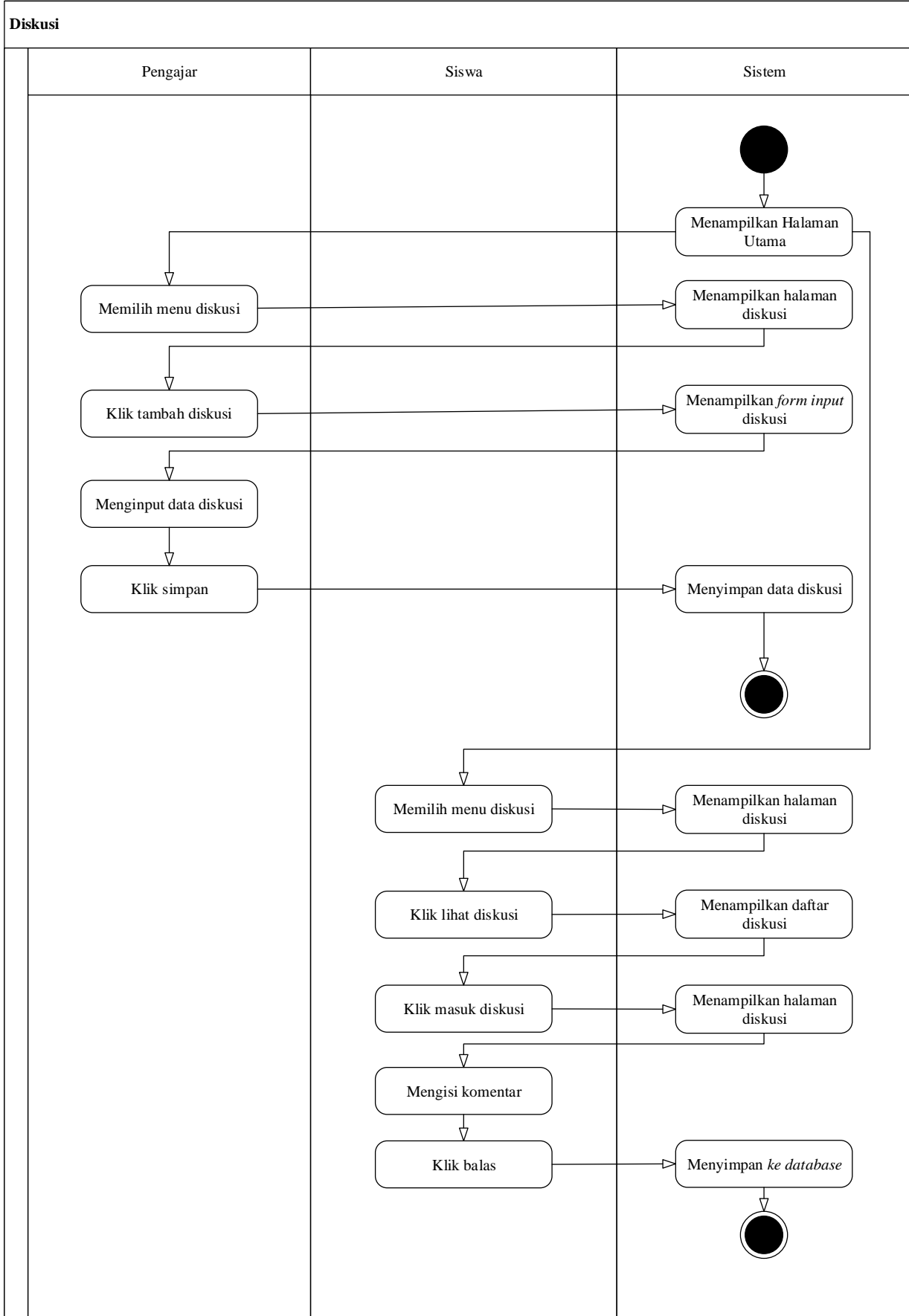

Gambar 4 Acitivity Diagram Forum Diskusi 
Berikut adalah class diagram yang diusulkan:

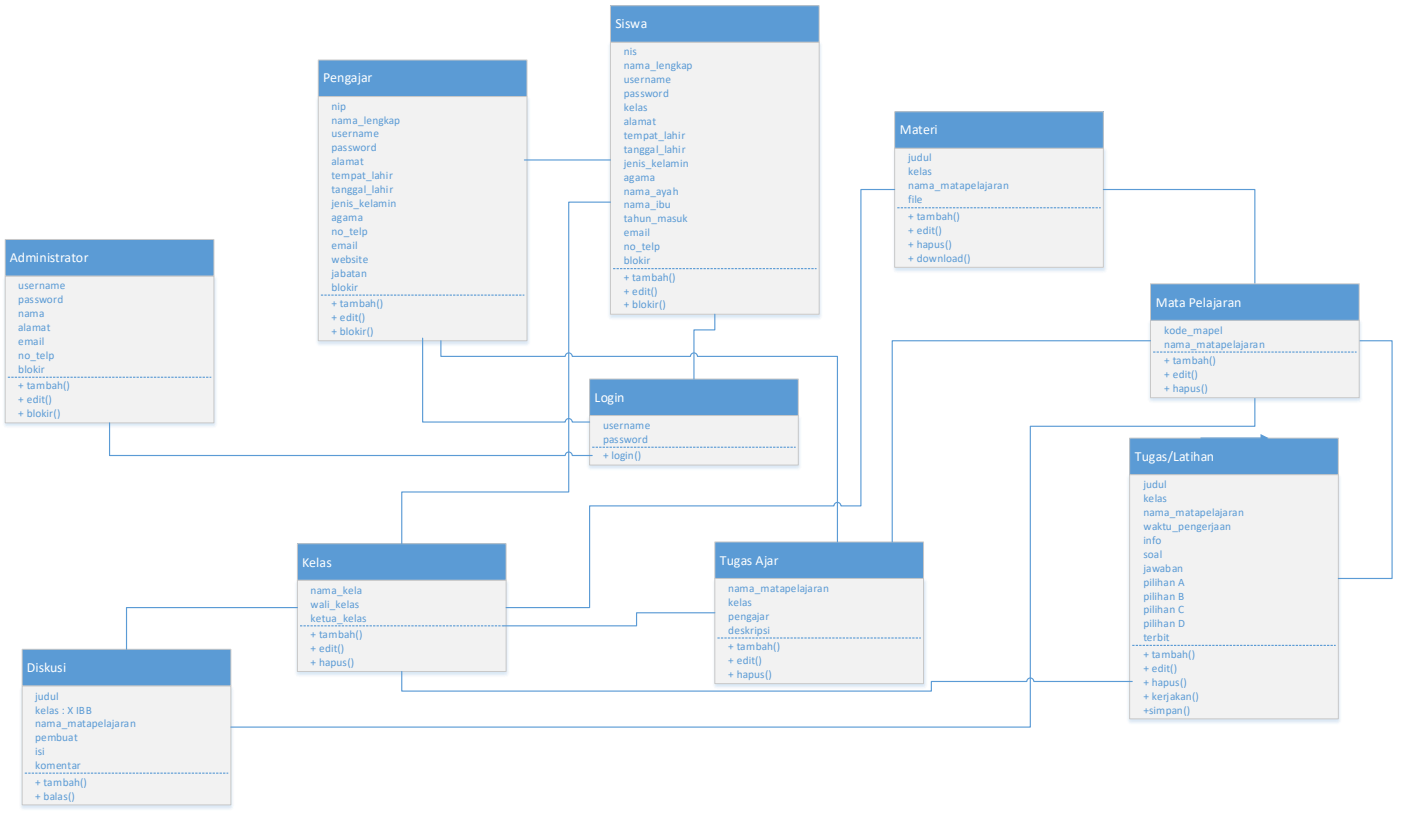

Gambar 5 Class Diagram

Setelah melakukan analisis, selanjutnya merancang antarmuka. Berikut beberapa antarmuka yang telah dirancang, diantaranya: halaman daftar materi, daftar tugas/latihan, form diskusi, dan halaman nilai. Halaman daftar materi dapat diakses oleh guru sebagai media untuk menyampaikan materi pada siswa, seperti pada gambar 7 .

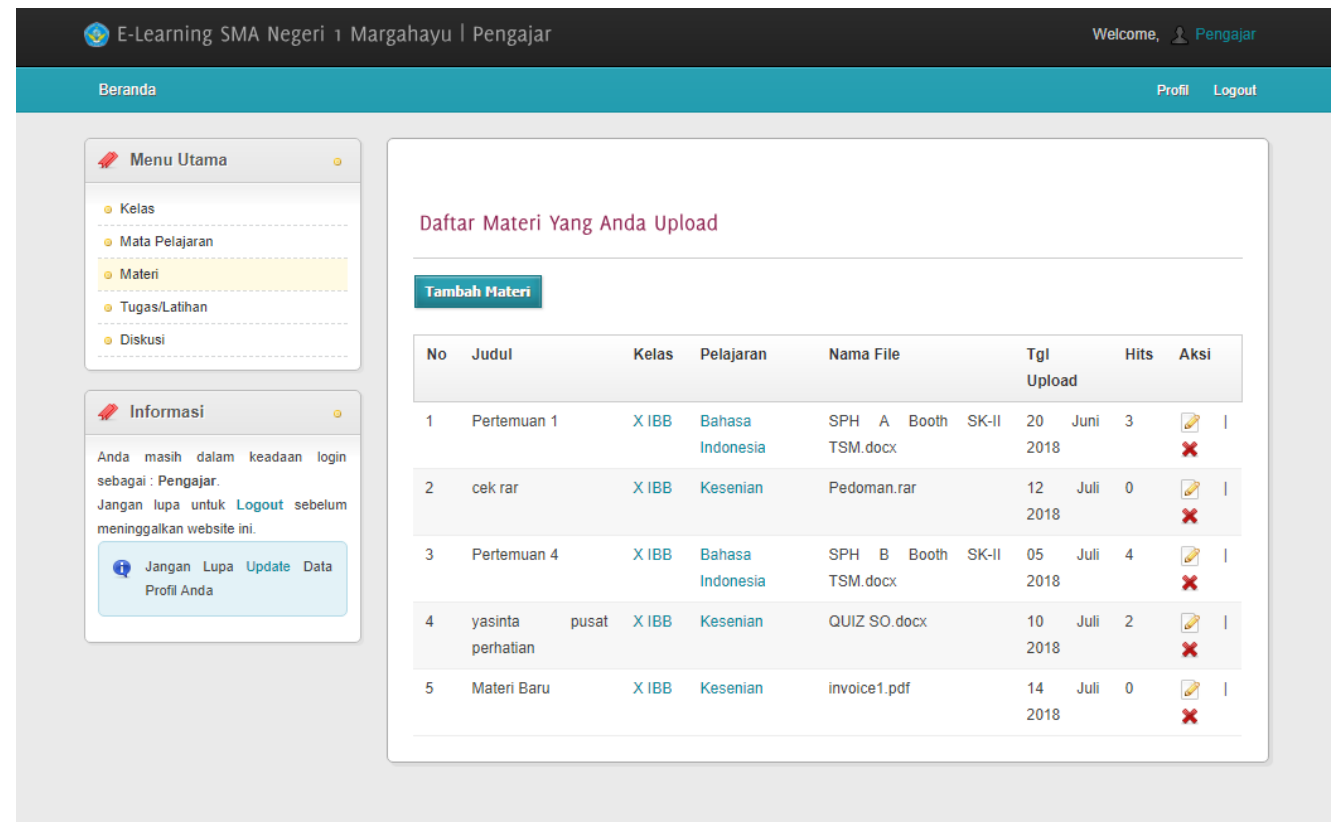

Gambar 6 Halaman Materi

Halaman daftar tugas digunakan guru untuk menyampaikan tugas maupun soal latihan yang harus dikerjakan siswa secara online, terlihat pada gambar 8 . 


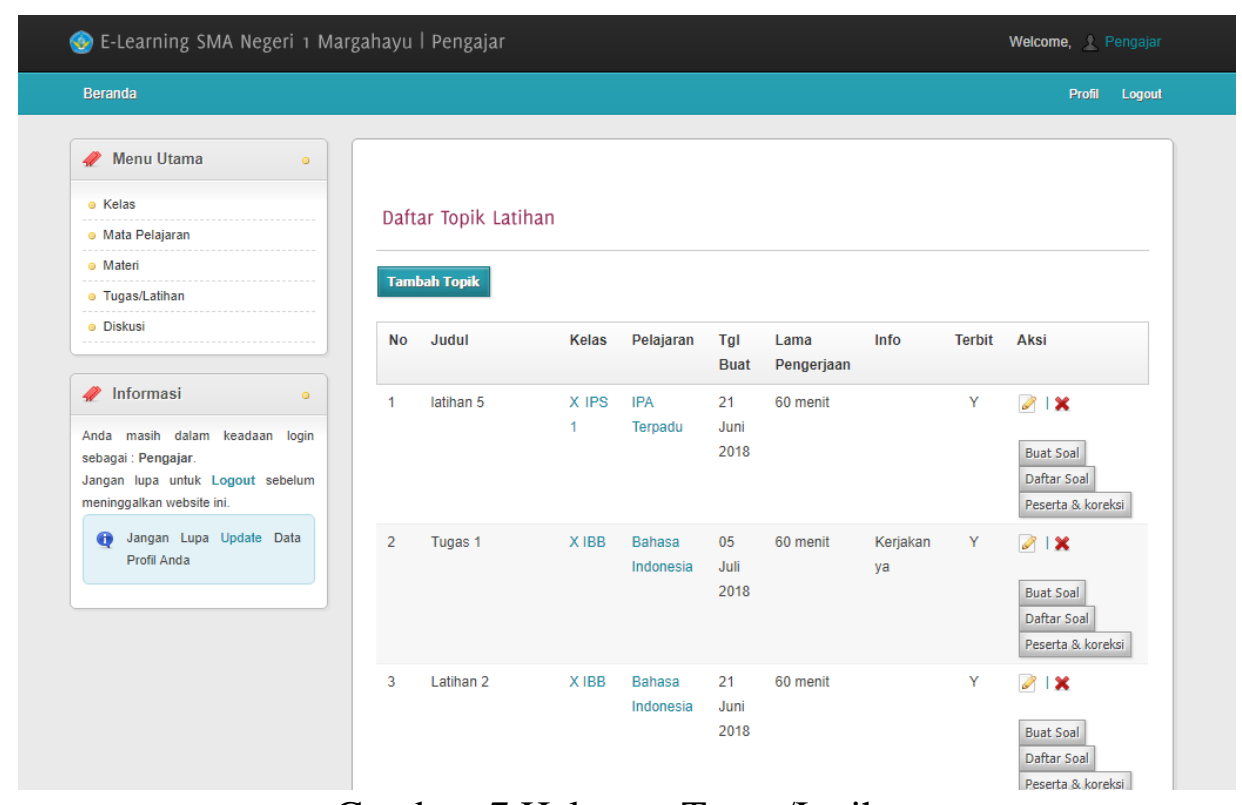

Gambar 7 Halaman Tugas/Latihan

Form diskusi diciptakan guru setelah materi telah disampaikan di kelas. Hal ini, untuk membantu interaksi siswa dengan guru ketika tidak berada dalam kelas. Form diskusi akan expired secara otomatis setelah tiga hari dibuka. Tampilan form diskusi seperti terlihat pada gambar 9 .

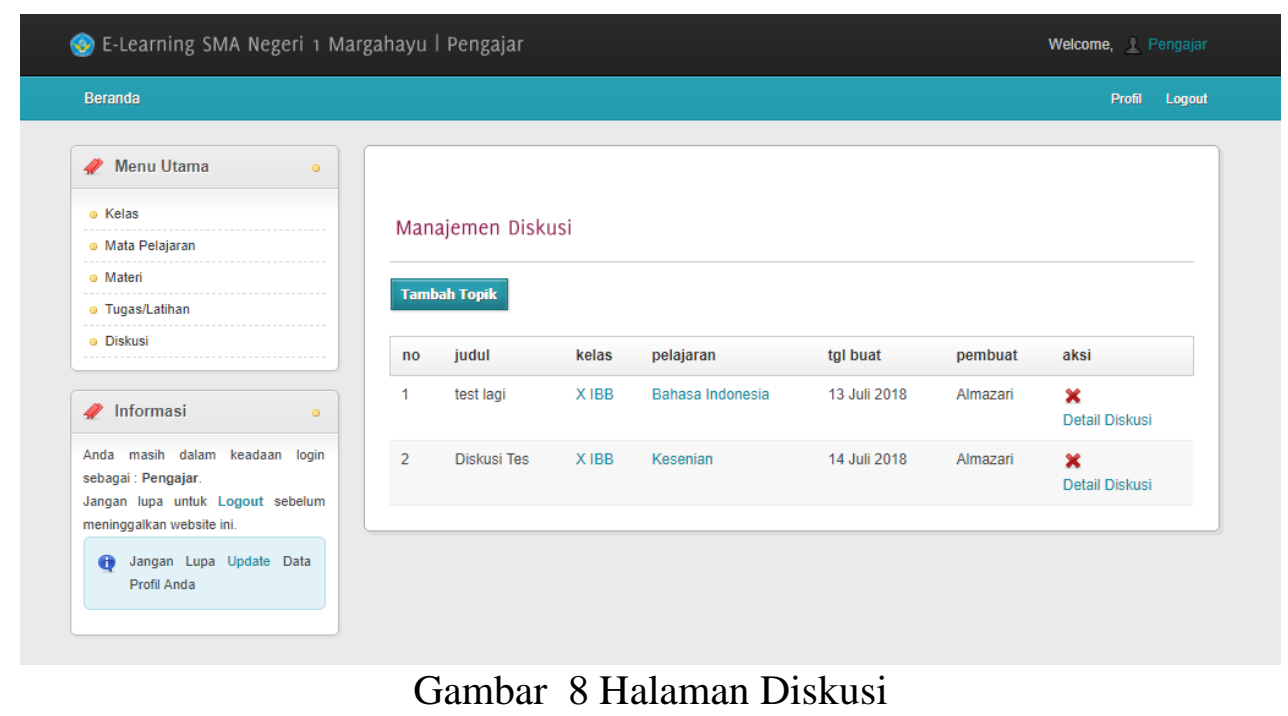

Halaman nilai akan muncul setelah siswa mengisi tugas ataupun latihan yang diberikan guru. Berikut halaman nilai yang dapat diakses siswa terlihat pada gambar 10 . 


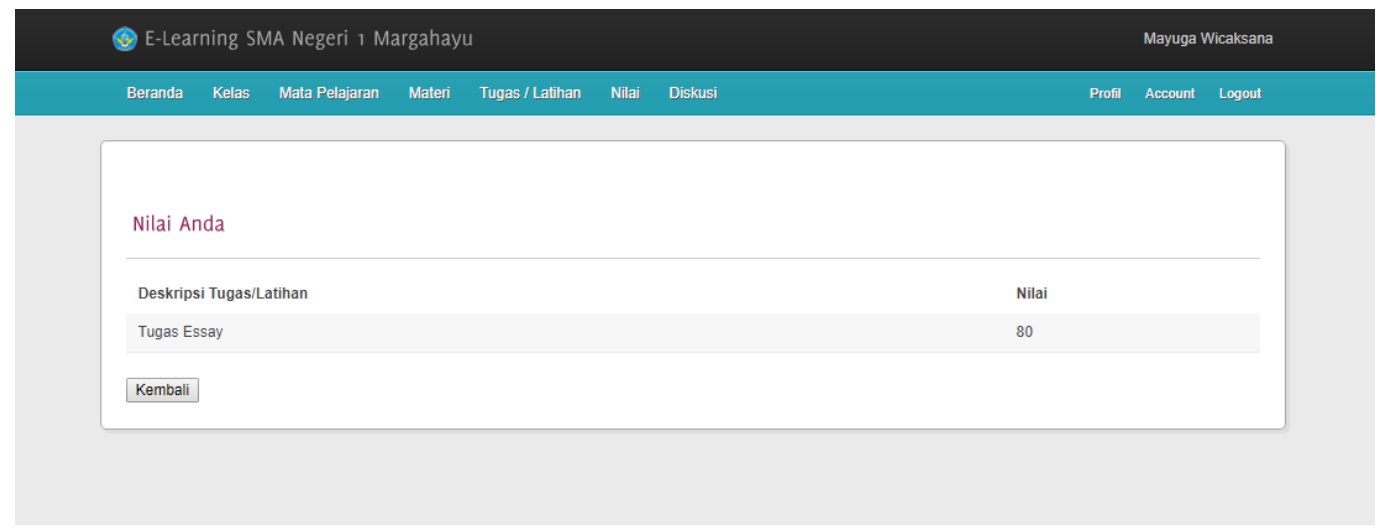

Gambar 9 Halaman Nilai

Pengujian dilakukan untuk mengetahui apakah sistem berjalan sesuai dengan fungsinya dan menghasilkan output yang diharapkan. Pengujian dilakukan terhadap form e-learning, salah satunya pada form penambahan materi. Hasil pengujian seperti terlihat pada tabel 1.

Tabel 1 Pengujian Form Tambah Materi

\begin{tabular}{|c|c|c|c|}
\hline \multicolumn{4}{|c|}{ Kasus dan Hasil Pengujian Data Normal } \\
\hline Skenario Uji & $\begin{array}{c}\text { Yang } \\
\text { Diharapkan }\end{array}$ & Pengamatan & Kesimpulan \\
\hline $\begin{array}{l}\text { Input data materi } \\
\text { dan upload file }\end{array}$ & $\begin{array}{l}\text { Data materi } \\
\text { tersimpan ke } \\
\text { database }\end{array}$ & $\begin{array}{l}\text { Data materi } \\
\text { tersimpan ke } \\
\text { database }\end{array}$ & $\begin{array}{l}\text { [ X ] Diterima } \\
\text { [ ] Ditolak }\end{array}$ \\
\hline \multicolumn{4}{|c|}{ Kasus dan Hasil Pengujian Data Salah } \\
\hline Skenario Uji & $\begin{array}{c}\text { Yang } \\
\text { Diharapkan }\end{array}$ & Pengamatan & Kesimpulan \\
\hline $\begin{array}{l}\text { Input data materi } \\
\text { dan upload file } \\
\text { selain (zip, rar, } \\
\text { doc, docx, ppt, } \\
\text { pptx, pdf ) }\end{array}$ & $\begin{array}{l}\text { Data tidak } \\
\text { tersimpan ke } \\
\text { database dan } \\
\text { menampilkan } \\
\text { pesan error file } \\
\text { tidak diizinkan }\end{array}$ & $\begin{array}{l}\text { Menampilkan } \\
\text { pesan error file } \\
\text { tidak diijinkan }\end{array}$ & $\begin{array}{l}\text { [ X ] Diterima } \\
\text { [ ] Ditolak }\end{array}$ \\
\hline
\end{tabular}

\section{Kesimpulan}

Perancangan e-learning di SMAN 1 Margahayu dapat terselesaikan. Rancangan sistem informasi ini dapat memfasilitasi pengajar dalam mendistribusikan material pelajaran. Melalui forum diskusi siswa, komunikasi interaktif antara pengajar dengan siswa dapat meningkatkan kemampuan pengetahuan siswa.

Fitur tugas dan latihan online dapat membantu pengajar dalam mengevaluasi kemampuan siswa. Tidak hanya itu, siswapun dapat melihat hasil tugas dan latihan yang dikerjakannya sehingga dapat mengukur dan mengevaluasi kemampuan belajarnya 


\section{Daftar Pustaka}

[1] Horton, William dan Horton, Katherine. E-Learning Tools and Technologies: A Consumer Guide for Trainers, Teachers, Educators, and Instructional Designers USA: Wiley Publishing, Inc. 2003.

[2] E. Karwati, "Pengaruh Pembelajaran Elektronik (E-Learning) Terhadap Mutu Belajar Mahasiswa”, Jurnal Penelitian Komunikasi, Vol. 17, No.1, Juli, pp:41-54. 2014.

[3] Abdillah, Leon Andretti. Students Learning Centre Strategy Based on E-Learning and Blogs. Providing SNST ke-4 Tahun 2013, Fakultas Teknik Universitas Wahid Hasyim Semarang. 2013.

[4] Edy, Irwan Christanto. Studi Pemanfaatan Web Site E-Learning dan Pengaruhnya Terhadap Motivasi, Kinerja dan Basil Belajar Pada Pengajar dan Sisa SMK di Provinsi Jawa Tengah. 2011.

[5] Sukamto, Binar Cipta Anggara. E-learning Jaringan Komputer Berbasis Web dan Aplikasi Mobile. Journal Teknik Elektro, Vol.1 No. 2 Augustus 2012: 75-85. 2012.

[6] Paramitha, Annisa. Pembangunan Aplikasi E-Learning Interaktif untuk Kelas X pada Mata Pelajaran Biologi Studi Kasus SMAN 15 Bandung. 2015.

[7] L.B. Al-Bahra. Analisis dan Desain Sistem Informasi, Yogyakarta: Graha Ilmu, 2005.

[8] Yakub, Pengantar Sistem Informasi, Yogyakarta: Graha Ilmu, 2012.

[9] A. Kristanto. Perancangan Sistem Informasi dan Aplikasinya, Yoyakarta: Gava Media, 2008.

[10] S. Much. Fuad. E-Learning dalam Persepsi Mahasiswa. Varia Pendidikan. Vol. 29 No.2, Desember 2017:102-109. 2017. 